\title{
EFFORTS TO IMPROVE CIVICS EDUCATION LEARNING ACHIEVEMENT THROUGH LEARNING METHOD C OOPERATIF MODEL STAD (STUDENT TEAMS ACHIEVEMENT DIVISION) IN CLASS STUDENT OF X SM A NEGERI 2 SUTERA YEAR LESSON 2016
}

\author{
SOFYAN
}

Volume 1 Nomor 1

JIPS ISSN: 2579-5449

\begin{abstract}
Learning activities together can help stimulate active learning. Teaching and learning in the classroom is to stimulate active learning, but the ability to teach through small group collaborative activities will allow to promote active learning activities in a special way. What was discussed student with his friends and what it teaches students to his friends allows them to gain an understanding and mastery of subject matter.

This study is based on the problem: (a) How can increase learning achievement Civics with the implementation of cooperative learning method STAD model? (B) How will the cooperative learning method on motivation to learn civics?.

While the purpose of this study was: (a) Want to know Civics increase learning achievement after the implementation of cooperative learning. (B) Want to know the effect of motivation to learn civics after the implementation of cooperative learning. (C)

provide an overview of appropriate learning methods in an effort to improve student achievement and make students actively in learning activities.

This study uses action research (action research) three rounds. each round consists of four stages: design, activity and observation, reflection, and refisi. Goal of this research is class X BC A Negeri 2 Sutera in the school year $2016 / 2017$. Data obtained in the form of a formative test results, observation sheet teaching and learning activities.

From the analysis we found that student achievement increased from the first cycle to the third cycle, the first cycle $(68.42 \%)$, the second cycle $(81.58 \%)$, the third cycle $(94.74 \%)$.

Conclusions from this research is cooperative learning methods can be a positive influence on students' motivation achievement and class X SM A Negeri 2 Sutera Year Lesson $2016 / 2017$ and this model can be used as an alternative civics lesson.
\end{abstract}

Keywords: improving performance

UPAYA MENINGKATKAN PRESTASI BELAJAR PKN MELALUI METODE
PEMBELAJARAN COOPERATIF MODEL STAD (STUDENT TEAMS ACHIEVEMENT
DIVISION ) PADA SISWA KELAS X SMA NEGERI 2 SUTERA TAHUN PELAJARAN 2016

ABSTRAK

Kegiatan belajar bersama dapat belajar dan mengajar di kelas memang dapat membantu memacu belajar aktif. Kegiatan menstimulasi belajar aktif, namun kemampuan 


\section{Jurnal Ilmiah Pendidikan Scholastic}

untuk mengajar melalui kegiatan kerjasama kelompok kecil akan memungkinkan untuk menggalakkan kegiatan belajar aktif dengan cara khusus. Apa yang didiskusikan siswa dengan teman-temannya dan apa yang diajarkan siswa kepada teman-temannya memungkinkan mereka untuk memperoleh pemahaman dan penguasaan materi pelajaran.

Penelitian ini berdasarkan permasalahan : (a) Bagaimanakah peningkatan prestasi belajar PKn dengan diterapkannya metode pembelajaran kooperatif model STAD ? (b) Bagaimanakah pengaruh Metode Pembelajaran kooperatif terhadap motivasi belajar PKn?.

Sedangkan tujuan dari penelitian ini adalah: (a) Ingin mengetahui peningkatan prestasi belajar PKn setelah diterapkannya pembelajaran kooperatif. (b) Ingin mengetahui pengaruh motivasi belajar PKn setelah diterapkannya pembelajaran kooperatif. (c) memberikan gambaran metode pembelajaran yang tepat dalam upaya meningkatkan prestasi

\section{Kata kunci : meningkatkan prestasi}

\section{PENDAHULUAN}

Latar Belakang Masalah, Guru memiliki peranan yang sangat penting dalam menentukan kuantitas dan kualitas pengajaran yang dilaksanakan. Oleh sebab itu, guru harus memikirkan dan membuat perencanaan secaraa seksama dalam meningkatkan kesempatan belajar bagi siswanya dan memperbaiki kualitas mengajarnya.

Hal ini menuntut perubahan-perubahan dalam mengorganisasikan kelas, penggunaan metode mengajar, strategi belajar mengajar, maupun sikap dan karakteristik guru dalam mengelola proses belajar mengajar. Guru berperan sebagai pengelola proses belajarmengajar, bertindak sebagai fasilitor yang berusaha mencipatakan kondisi belajar mengajar yang efektif, sehingga memungkinkan proses belajar mengajar, mengembangkan bahan pelajaran dengan baik, dan meningkatkan kemampuan siswa untuk menyimak pelajaran dan menguasai tujuan-tujuan pendidikan yang harus mereka capai. Untuk memenuhi hal tersebut di atas, guru dituntut mampu mengelola proses belajar mengajar yang memberikan rangsangan kepada siswa, sehingga ia mau belajar karena siswalah subyek utama dalam belajar. belajar siswa dan menjadikan siswa aktif dalam kegiatan belajar mengajar.

Penelitian ini menggunakan penelitian tindakan (action research) sebanyak tiga putaran - setiap putaran terdiri dari empat tahap, yaitu : rancangan, kegiatan dan pengamatan, refleksi, dan refisi. Sasaran penelitian ini adalah siswa kelas X SMA Negeri 2 Sutera Tahun Pelajaran 2016/2017. Data yang diperoleh berupa hasil tes formatif, lembar observasi kegiatan belajar mengajar.

Dari hasil analisis didapatkan bahwa prestasi belajar siswa mengalami peningkatan dari siklus I sampai siklus III, yaitu siklus I $(68,42 \%)$, siklus II $(81,58 \%)$, siklus III $(94,74 \%)$. Simpulan dari penelitian ini adalah metode pembelajaran kooperatif dapat berpengaruh positif terhadap prestasi dan motivasi belajar siswa kelas X SMA Negeri 2 Sutera Tahun Pelajaran 2016/2017 serta model pembelajaran ini dapat digunakan sebagai salah satu alternative pembelajaran PKn.
Mengajar adalah membimbing belajar siswa sehingga ia mampu belajar. Dengan demikian aktifitas siswa sangat diperlukan dalam kegiatan belajar-mengajar sehingga siswalah yang seharusnya banyak aktif, sebab siswa sebagai subyek didik adalah yang merencanakan, dan ia sendiri yang melaksanakan belajar.

Pada kenyataan, di sekolah-sekolah seringkali guru yang aktif, sehingga siswa tidak diberi kesempatan untuk aktif.

Kegiatan belajar bersama dapat membantu memacu belajar aktif. Kegiatan belajar dan mengajar di kelas memang dapat menstimulasi belajar aktif. Namun kemampuan untuk mengajar melalui kegiatan kerjasana kelompok kecil akan memungkinkan untuk menggalakkan kegiatan belajar aktif dengan cara khusus. Apa yang didiskusikan siswa dengan teman-temannya dan apa yang diajarkan siswa kepada teman-temannya memungkinkan mereka untuk memperoleh pemahaman dan penguasaan materi pelajaran.

Pembelajaran PKn tidak lagi mengutamakan pada penyerapan melalui pencapaian informasi, tetapi lebih mengutamakan pada pengembangan kemampuan dan pemrosesan informasi. Untuk itu aktifitas 


\section{Jurnal Ilmiah Pendidikan Scholastic}

peserta didik perlu ditingkatkan melalui latihanlatihan atau tugas dengan bekerja dalam kelompok kecil dan menjelaskan ide-ide kepada orang lain. (Hartoyo, 2000:24).

Pembelajaran kooperatif lebih menekankan interaksi antar siswa. Dari sini siswa akan melakukan komunikasi aktif dengan sesama temannya. Dengan komunikasi tersebut diharapkan siswa dapat menguasai materi pelajaran dengan mudah karena "siswa lebih mudah memahami penjelasan dari kawannya dibanding penjelasan dari guru, karena taraf pengetahuan serta pemikiran mereka lebih sejalan dan sepadan". (Sulaiman dalam Wahyuni 2001: 2).

Pete Tschumi dari Universitas Arkansas Little Rock memperkenalkan suatu ilmu pengetahuan pengantar pelajaran komputer selama tiga kali, yang pertama siswa bekerja secaraa individu, dan dua kali secaraa kelompok. Dalam kelas pertama hanya $36 \%$ siswa yang mendapat nilai $\mathrm{C}$ atau lebih baik, dan dalam kelas yang bekerja secaraa kooperatif ada $58 \%$ dan $65 \%$ siswa yang mendapat nilai $\mathrm{C}$ atau lebih

Berdasarkan paparan tersebut di atas, maka peneliti ingin mencoba melakukan penelitian dengan judul "Upaya Meningkatkan Prestasi Belajar PKn Melalui Metode Pembelajaran Kooperatif Model STAD (Student Teams Achievement Division) Pada Siswa Kelas $X$ SMA Negeri 2 Sutera Tahun Pelajaran 2016/2017.

Bertitik tolak dari latar belakang di atas, maka penulis merumuskan permasalahannya sebagai berikut: (1) Bagaimanakah peningkatan prestasi belajar PKn dengan diterapkannya metode pembelajaran kooperatif model STAD baik (Felder, 199: 14).

pada siswa kelas X SMA Negeri 2 Sutera Tahun Pelajaran 2016/2017 ?. (2) Bagaimanakah pengaruh metode pembelajaran kooperatif model STAD terhadap motivasi belajar PKn pada siswa kelas X SMA Negeri 2 Sutera Tahun Pelajaran 2016/2017?

Sesuai dengan permasalahan di atas, penelitian ini bertujuan untuk: (1) Mengetahui peningkatan prestasi belajar PKn setelah diterapkannya pembelajaran kooperatif model STAD pada siswa kelas X SMA Negeri 2 Sutera Tahun Pelajaran 2016/2017. (2) Mengetahui pengaruh motivasi belajar PKn setelah diterapkannya pembelajaran kooperatif model STAD pada siswa kelas X SMA Negeri 2 Sutera Tahun Pelajaran 2016/2017. (3) Memberikan gambaran tentang metode pembelajaran yang tepat dalam upaya meningkatkan prestasi belajar siswa dan menjadikan siswa menjadi aktif dalam kegiatan belajar mengajar.

Berdasarkan pada permasalahan dalam penelitian tindakan yang berjudul "Upaya Meningkatkan Prestasi Belajar PKn melalui Metode Pembelajaran Kooperatif Model STAD (Student Teams Achievement Division) Pada Siswa Kelas X SMA Negeri 2 Sutera Tahun Pelajaran 2016/2017" yang dilakukan oleh peneliti, dapat dirumuskan hipotesis tindakan sebagai berikut:

"Jika Proses Belajar Mengajar Siswa Kelas X SMA Negeri 2 Sutera Tahun Pelajaran 2016/2017, menggunakan metode STAD dalam menyampaikan materi pembelajaran, maka dimungkinkan minat belajar dan hasil belajar siswa kelas X SMA Negeri 2 Sutera Tahun Pelajaran 2016/2017 akan lebih baik dibandingkan dengan proses belajar mengajar yang dilakukan oleh guru sebelumnya".

\section{METODOLOGI PENELITIAN}

Penelitian ini merupakan penelitian tindakan (action research), karena penelitian dilakukan untuk memecahkan masalah pembelajaran di kelas. Penelitian ini juga termasuk penelitian deskriptif, sebab menggambarkan bagaimana suatu teknik pembelajaran diterapkan dan bagaimana hasil yang diinginkan dapat dicapai.

Menurut Sukidin dkk. (2002:54) ada 4 macam bentuk penelitian tindakan yaitu: (1) penelitian tindakan guru sebagai peneliti, (2) penelitian tindakan kolaboratif, (3) penelitian tindakan simultan terintegratif, dan (4) penelitian tindakan sosial eksperimental.
Keempat bentuk penelitian tindakan di atas, ada persamaan dan perbedaannya. Menurtut Oja dan SMA 2 yang sebagaimana dikutip oleh Kasbolah, (2000) (dalam Sukidin, dkk. 2002 : 55), ciri-ciri dari setiap penelitian tergantung pada : (1) tujuan utamanya atau pada tekanannya, (2) tingkat kolaborasi antara pelaku peneliti dan peneliti dari luar, (3) proses yang digunakan dalam melakukan penelitian, dan (4) hubungan antar proyek dengan sekolah.

Dalam penelitian ini menggunakan bentuk guru sebagai peneliti, dimana guru sangat berperan sekali dalm proses penelitian tindakan kelas. Dalam bentuk ini, tujuan utama penelitian 


\section{Jurnal Ilmiah Pendidikan Scholastic}

tindakan kelas ialah untuk meningkatkan praktikpraktik pembelajaran di kelas. Dalam kegiatan ini guru terlibat langsung secara penuh dalam proses perencanaan, tindakan, observasi, dan refleksi. Kehadiran pihak lain dalam penelitian ini perananya tidak dominan dan sangat kecil.

Penelitian ini mengacu pada perbaikan pembelajaran yang berkesinambungan. Kemmis dan Tagart (1988:14) menyatakan bahwa model penelitian tindakan adalah berbentuk spiral. Tahapan penelitian tindakan pada suatu siklus meliputi perencanaan atau pelaksanaan observasi dan refleksi. Siklus ini berlanjut dan akan dihentikan jika sesuai dengan kebutuhan dan dirasa sudah cukup.

Tempat, Waktu dan Subjek Penelitian, Tempat penelitian adalah tempat yang digunakan dalam melakukan penelitian untuk memperoleh data yang diinginkan. Penelitian ini bertempat di SMA 2 Sutera Tahun Pelajaran 2016/2017. Waktu penelitian adalah waktu berlangsungnya penelitian atau saat penelitian ini dilangsungkan. Penelitian ini dilaksanakan pada bulan Agustus Oktober semester ganjil tahun ajaran 2016/2017. Subjek penelitian adalah siswa-siswi kelas $\mathrm{X}$ SMA Negeri 2 Sutera Tahun Pelajaran 2016/2017 pada Kompetensi Dasar : Menunjukan sikap positif terhadap norma-norma yang berlaku dalam kehidupan bermasyarakat, berbangsa dan bernegara

Menurut pengertiannya penelitian tindakan adalah penelitian tentang hal-hal yang terjadi di masyarakat atau sekelompok sasaran, dan hasilnya langsung dapat dikenakan pada masyarakat yang bersangkutan (Arikunto, Suharsimi 2002: 82). Ciri atau karakteristik utama dalam penelitian tindakan adalah adanya partisipasi dan kolaborasi antara peneliti dengan anggota kelompok sasaran. Penelitian tindakan adalah satu strategi pemecahan masalah yang memanfaatkan tindakan nyata dalam bentuk proses pengembangan inovatif yang dicoba sambil jalan dalam mendeteksi memecahkan masalah. Dalam prosesnya pihak-pihak yang terlibat dalam kegiatan teersebut dapat mendukung satu sama lain.

Sedangkan tujuan penelitian tindakan harus memenuhi beberapa prinsip sebagai berikut : (1) Permasalahan atau topik yang dipilih harus memenuhi kriteria, yaitu benar-benar nyata dan penting, menarik perhatian dan mampu ditangani serta dalam jangkauan kewenangan peneliti untuk melakukan perubahan. (2) Kegiatan penelitian, baik intervensi maupun pengamatan yang dilakukn tidak boleh sampai mengganggu atau menghambat kegiatan utama. (3) Jenis intervensi yang dicobakan harus efektif dan efisien. (3) Metodologi yang harus jelas, rinci dan terbuka, setiap langkah dari tindakan dirumuskan dengan tegas, sehingga orang yang berminat terhadap penelitian tersebut dapat mengecek setiap hipotesis dan pembuktiannya. (4) Kegiatan penelitian diharapkan dapat merupakan proses kegiatan yang berkelanjutan (on-going), mengingat bahwa pengembangan dan perbaikan terhadap kualitas tindakan memang tidak dapat berhenti tetapi menjadi tantangan setiap waktu. (Arikunto, Suharsimi, 2002: 8283).

Sesuai dengan jenis penelitian yang dipilih, yaitu penelitian tindakan, maka penelitian ini menggunakan model penelitian tindakan dari Kemmis dan Taggart (dalam Arikunto, Suharsimi, 2002: 83), yaitu berbentuk spiral dari siklus yang satu ke siklus yang berikutnya. Setiap siklus meliputi planning (rencana), action (tindakan), observation (pengamatan), dan reflection (refleksi). Langkah pada siklus berikutnya adalah perencanaan yang sudah direvisi, tindakan, pengamatan, dan refleksi. Sebelum masuk pada siklus I dilakukan tindakan pendahuluan yang berupa identifikasi permasalahan. Siklus spiral dari tahap-tahap penelitian tindakan kelas dapat dilihat pada gambar berikut : 


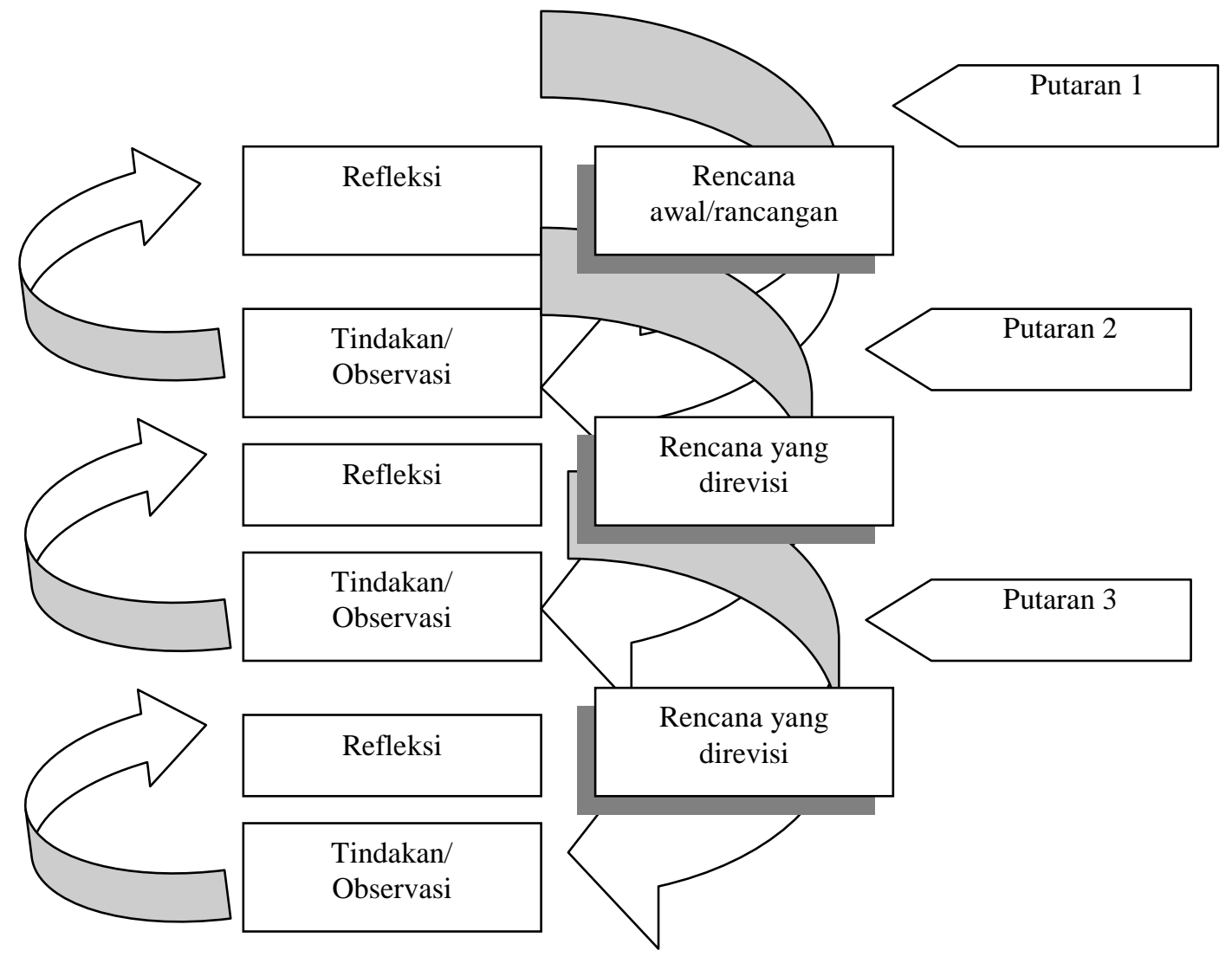

Gambar 3.1. Alur PTK

Penjelasan alur diatas adalah : (1) Rancangan/ rencana awal, sebelum mengadakan penelitian peneliti menyusun rumusan masalah, tujuan dan membuat rencana tindakan, termasuk di dalamnya instrument penelitian dan perangkat pembelajaran. (2) Kegiatan dan pengamatan, meliputi tindakan yang dilakukan oleh peneliti sebagai upaya membangun pemahaman konsep siswa serta mengamati hasil atau dampak dari diterapkannya metode pembelajaran kooperatif model STAD. (3) Refleksi, peneliti mengkaji, melihat dan mempertimbangkan hasil atau dampak dari tindakan yang dilakukan berdasarkan lembar pengamatan yang diisi oleh pengamat. (4) Rancangan/ rencana yang direvisi, berdasarkan hasil refleksi dari pengamat membuat rancangan yang direvisi untuk dilaksanakan pada siklus berikutnya.

Observasi dibagi dalam 3 putaran, yaitu putaran 1,2 dan 3, dimana masing putaran dikenai perlakuan yang sama (alur kegiatan yang sama) dan membahas satu sub pokok bahasan yang diakhiri dengan tes formatif di akhir masing putaran. Dibuat dalam tiga putaran dimaksudkan untuk memperbaiki sistem pengajaran yang telah dilaksanakan.

Alat pengumpul data dalam penelitian ini adalah tes buatan guru yang fungsinya adalah: (1) Untuk menentukan seberapa baik siswa telah menguasai bahan pelajaran yang telah diberikan dalam waktu tertentu; (2) Untuk menentukan apakah suatu tujuan telah tercapai; dan (3) Untuk memperoleh suatu nilai (Arikunto, Suharismi, 2002: 19). Sedangkan tujuan dari tes adalah untuk mengetahui ketuntasan belajar siswa secaraa individual maupun secaraa klasikal. Disamping itu untuk mengetahui letak kesalahankesalahan yang dilakukan siswa sehingga dapat dilihat dimana kelemahannya, khususnya pada bagian mana TPK yang belum tercapai. Untuk memperkuat data yang dikumpulkan, maka juga digunakan metode observasi (pengamatan) yang dilakukan oleh teman sejawat untuk mengetahui dan merekam aktifitas guru dan siswa dalam 


\section{Jurnal Ilmiah Pendidikan Scholastic}

proses belajar mengajar.

Untuk mengetahui kefektivan suatu metode dalam kegiatan pembelajaran perlu diadakan analisis data. Pada penelitian ini menggunakan teknik analisis dekriptif kualitatif, yaitu suatu metode penelitian yang bersifat menggambarkan kenyataan atau fakta sesuai dengan data yang diperoleh dengan tujuan untuk mengetahui prestasi belajar yang dicapai siswa, juga untuk memperoleh respon siswa terhadap kegiatan pembelajaran serta aktivitas siswa selama proses pembelajaran.

Untuk menganalisi tingkat keberhasilan atau presentase keberhasilan siswa setelah proses belajar mengajar setiap putarannya dilakukan dengan cara memberikan evaluasi berupa soal tes tertulis paa setiap akhir putaran.

Analisi ini dihitung dengan menggunakan statistik sederhana yaitu :

Untuk menilai ulangan atau tes formatif, Peneliti melakukan penjumlahan nilai yang diperoleh siswa, yang selanjutnya dibagi dengan jumlah siswa yang ada di kelas tersebut sehingga diperoleh rata-rata tes formatif dapat dirumuskan

$$
\mathrm{X}=\frac{\Sigma x-}{\Sigma \mathrm{N}}
$$

Dengan

$$
: \mathrm{X}=\overline{\text { Nilai rata-rata }}
$$$$
\sum \mathrm{X}=\text { Jumlah semua nilai }
$$

siswa

$$
\sum \mathrm{N}=\text { Jumlah siswa }
$$

Untuk ketuntasan belajar, Ada dua kategori ketuntasan belajar yaitu secaraa perorangan dan secaraa klasikal. Berdasarkan petunjuk pelaksanaan belajar mengajar kurikulum 1994 (Depdikbud, 1994), yaitu seorang siswa telah tuntas belajar bila telah mencapai skor $65 \%$ atau nilai 65, dan kelas disebut tuntas belajar baik dikelas tersebut terdapat $85 \%$ yang telah mencapai daya serap lebih dari atau sama dengan $65 \%$. Untuk menghitung presentase ketuntasan belajar digunakan rumus sebagai berikut :

$100 \%$

$$
\mathrm{P}=\frac{\Sigma \text { Siswa.yang.tuntas.belajar }}{\Sigma \text { Siswa }} \mathrm{x}
$$

Untuk menghitung lembar observasi pengelolaan metode pembelajaran kooperatif model STAD digunakan rumus sebagai berikut :

$$
\overline{\mathrm{X}}=\frac{P 1+P 2}{2}
$$

Dimana P1 = Pengamat 1 dan $\mathrm{P} 2=$

Pengamat 2

Untuk menghitung lembar observasi aktifitas guru dan siswa digunakan rumus sebagai berikut :

$$
\begin{aligned}
& \%=\frac{\bar{x}}{\Sigma x} \times 100 \% \text { dengan } \\
& \overline{\mathrm{X}}=\frac{\text { Jumah.hasil.pengama } \tan }{\text { Jumlah.pengama } \tan }=
\end{aligned}
$$$$
\frac{P 1+P 2}{2}
$$

pengamatan

$$
\text { Dimana : } \%=\text { Presentase }
$$

rata

$$
\begin{array}{ll}
\overline{\mathrm{X}} & =\text { Rata-rata } \\
\sum \overline{\mathrm{x}} & =\text { Jumlah rata- }
\end{array}
$$

$$
\begin{array}{ll}
\mathrm{P} 1 & =\text { Pengamat } 1 \\
\mathrm{P} 2 & =\text { Pengamat } 2
\end{array}
$$

\section{HASIL PENELITIAN DAN PEMBAHASAN}

Data penelitian diperoleh dari data observasi berupa pengamatan perngelolaan metode pembelajaran kooperatif model STAD dan pengamatan aktivitas guru dan siswa pada setiap siklus.

Data lembar observasi diambil dari dua pengamatan yaitu data pengamatan pengelolaan metode pembelajaran kooperatif model STAD yang digunakan untuk mengetahui pengaruh penerapan metode pembelajaran kooperatif model STAD dalam meningkatkanprestasi belajar siswa dan data pengamatan aktivitas guru dan siswa.
Data tes formatif untuk mengetahui peneingkatan prestasi belajar siswa setelah diterapkannya metode pembelajaran kooperatif model STAD.

Siklus I, Tahap Perencanaan. Pada tahap ini peneliti mempersiapkan perangkat pembelajaran yang terdiri dari rencana pelajaran 1, soal tes formatif I dan alat-alat pengajaran yang mendukung. Selain itu juga dipersiapkan lembar observasi pengolahan metode pembelajaran kooperatif model STAD, dan lembar observasi aktifitas guru dan siswa.

Pelaksanaan kegiatan belajar mengajar 


\section{Jurnal Ilmiah Pendidikan Scholastic}

untuk siklus I dilakasanakan pada tanggal 4 Agustus 2016 di kelas X SMA 2 Sutera dengan jumlah siswa 38 siswa. Pelaksanaan metode pembelajaran kooperatif model STAD melalui tahapan sebagai berikut : (1) Pelaksanaan pembelajaran, (2) Diskusi kelompok, (3) Tes, (4) Penghargaan kelompok, (5) Menentukan nilai individual dan kelompok. Dalam hal ini peneliti bertindak sebagai pengajar, sedangkan yang bertindak sebagai pengamat adalah seorang guru PKn dan Wali Kelas X. Adapun proses belajr mengajar mengacu pda rencana pelajaran yang telah dipersiapkan. Pengamatan (observasi) dilaksanakan bersamaan dengan pelaksanaan dengan pelaksanaan belajar mengajar.

Pada akhir proses belajar mengjaar siswa diberi tes formatif I dengan tujuan untuk mengetahui tingkat keberhasilan siswa dalam proses belajar mengajar yang telah dilakukan.

Keterangan : Nilai : Kriteria 1): Tidak Baik 2) Kurang Baik 3) Cukup Baik 4) Baik.

Berdasarkan tabel di atas aspek-aspek yang mendapatkan kriteria kurang baik adalah memotivasi siswa, menyampaikan tujuan pembelajran, pengelolaan waktu, dan siswa antusias. Keempat aspek yang mendapat nilai kurang baik di atas, merupakan suatu kelemahan yang terjadi pada siklus I dan akan dijadikan bahan kajian untuk refleksi dan revisi yang akan dilakukan pada siklus II.

Berdasarkan tabel di atas tampak bahwa aktivitas guru yang paling dominan pada siklus I adalah membimbing dan mengamati siswa dalam menemukan konsep, yaitu 21,7 \%. Aktivitas lain yang presentasinya cukup besar adalah memberi umpan balik/ evaluasi, tanya jawab dan menjelaskan materi yang sulit yaitu masingmasing sebesar $13,3 \%$. Sedangkan aktivitas siswa yang paling dominan adalah mengerjakan/ memperhatikan penjelasan guru yaitu $22,5 \%$. Aktivitas lain yang presentasinya cukup besar adalah bekerja dengan sesama anggota kelompok, diskusi antara siswa/ antara siswa dengan guru, dan membaca buku yaitu masingmasing 18,7\% 14,4 dan 11,5\%.

Pada siklus I, secaraa garis besar kegiatan belajar mengajar dengan metode pembelajaran kooperatif model STAD sudah dilaksanakan dengan baik, walaupun peran guru masih cukup dominanuntuk memberikan penjelasan dan arahan, karena model tersebut masih dirasakan baru oleh siswa.

Dengan menerapkan metode pembelajaran kooperatif model STAD diperoleh nilai rata-rata prestasi belajar siswa adalah 6,79 dan ketuntasan belajar mencapai $68,42 \%$ atau ada 26 siswa dari 38 siswa sudah tuntas belajar. Hasil tersebut menunjukkan bahwa paDa siklus pertama secara klasikal siswa belum tuntas belajar, karena siswa yang memperoleh nilai $\geq 65$ hanya sebesar $68,42 \%$ lebih kecil dari presentase ketuntasan yangt dikehendaki yaitu sebesar $85 \%$. Hal ini disebabkan akrena siswa masih merasa baru dan belum mengerti apa yang dimaksudkan dan digunakan guru dengan menerapkan metode pembelajaran kooperatif model STAD.

Refleksi, Dalam pelaksanaan kegiatan belajar mengajar diperoleh informasi dari hasil pengamatan sebagai berikut : 1) Guru kurang maksimal dalam memotivasi siswa dan dalam menyampaikan tujuan pembelajaran. 2) Guru kurang bm,aksimal dalampengelolaan waktu 3) Siswa kurang aktif selama pembelajaran berlangsung

Analisis data penelitian siklus I, Ranah Psikomotor, Siswa yang mendapat nilai 60 tidak ada, Siswa yang mendapat nilai 70 sebanyak 15 $(38,46 \%)$, Siswa yang mendapat nilai 80 sebanyak 2 (61,54\%), Berarti siswa yang mendapat nilai di atas 70 sebanyak $61,54 \%$, secaraa klasikal termasuk kategori belum tuntas.

Ranah Afektif, Siswa mendapat nilai C sebanyak $6(15,38 \%)$, Siswa yang mendapat nilai B sebanyak $26(66,67 \%)$, Siswa yang mendapat nilai A sebanyak 7 (17,95\%). Berarti siswa yang mendapat nilai di atas C sebanyak 84,62\%, secaraa klasikal termasuk kategori tuntas.

Refisi, Pelaksanaan kegiatan belajar mengajar pada siklus I ini masih terdapat kekurangan, sehingga perlu adanya revisi untuk dilakukan pada siklus berikutnya. 1) Guru perlu lebih terampil dalam memotivasi siswa dan lebih jelas dalam menyampaikan tujuan pembelajaran. Dimana siswa diajak untuk terlibat langsung dalam setiap kegiatan yang akan dilakukan. 2) Guru perlu mendistribusikan waktu secara baik dengan menambahkan informasi-informasi yang dirasa perlu dan memberi catatan 3) Guru harus lebih terampil dan bersemangat dalam memotivasi siswa sehingga siswa bisa lebih antusias.

Siklus II, Tahap perencanaan

Pada tahap ini peneliti mempersiapkan perangkat pembelajaran yang terdiri ari rencana pelajaran 2, soal tes formatif 2 dan alat-alat pengajaran yang mendukung. Selain itu juga dipersiapkan lembar observasi pengelolaan metode pembelajaran kooperatif model STAD dan lembar observasi guru dan siswa.

Pelaksanaan kegiatan belajar mengajar 


\section{Jurnal Ilmiah Pendidikan Scholastic}

untuk siklus II dilaksanakan paa tanggal 11 September 2016 di Kelas X dengan jumlah siswa 38 siswa. Pelaksanan metode pembelajaran kooperatif model STAD melalui tahapan sebagai berikut; (1) Pelaksanaan pembelajran, (2) Diskusi klompok, (3) Tes, (4) Penghargaan kelompok, (5) Menentukan nilai individual dan kelompok.

Dalam hal ini peneliti bertindak sebagai pengajar, sedangkan yang bertindak sebagi pengamat adalah seorang guru PKn dan Wali Kelas X. Adapun proses belajar mengajar mengacu paa rencana pelajaran dengan memperhatikan revisi pada siklus I, sehingga kesalahan atau kekurangan pada siklus I tidak terulang lagi pada siklus II. Pengamatan (observasi) dilaksanakanbersamaan dengan pelaksanaan belajar mengajar.

Pada akhir proses belajar mengajar siswa diberi tes formatif II dengan tujuan untuk mengetahui tingkat keberhasilan siswa dalam proses belajar mengajar yang telah dilakukan. Instrument yang digunakan adalah tes formatif II. Keterangan : Nilai: Kriteria : Tidak Baik : Kurang Baik : Cukup Baik : Baik .

Dari aspek-aspek yang diamati pada kegiatan belajar mengajar (siklus II) yang dilaksanakn oleh guru dengan menerapkan metode pembelajaran kooperatif model STAD mendapatkan penilaian yang cukup baik dari pengamat. Maksudnya dari seluruh penilaian tidak terdapat nilai kurang. Namun demikian penilaian tesebut belum merupakan hasil yang optimal, untuk itu ada beberapa aspek yang perlu mendapatkan perhatian untuk penyempurnaan penerapan pembelajaran selanjutnya. Aspekaspek tersebut adalah memotivasi siswa, membimbing siswa merumuskan kesimpulan/ menemukan konsep, dan pengelolaan waktu.

Tampak bahwa aktifitas guru yang paling dominan pada siklus II adalah membimbing dan mengamati siswa dalam menentukan konsep yaitu $25 \%$. Jika dibandingkan dengan siklus I, aktivitas ini mengalami peningkatan. Aktivitas guru yang mengalami penurunan adalah memberi umpan balik/evaluasi/ Tanya jawab (16,6\%), mnjelaskan materi yang sulit $(11,7)$. Meminta siswa mendiskusikan dan menyajikan hasil kegiatan $(8,2 \%)$, dan membimbing siswa merangkum pelajaran $(6,7 \%)$.

Sedangkan untuk aktivitas siswa yang paling dominan pada siklus II adalah bekerja dengan sesama anggota kelompok yaitu (21\%). Jika dibandingkan dengan siklus I, aktifitas ini mengalami peningkatan. Aktifitas siswa yang mengalami

penurunan

adalah

mendengarkan/memperhatikan penjelasan guru $(17,9 \%)$. Diskusi antar siswa/ antara siswa dengan guru $(13,8 \%)$, menulis yang relevan dengan $\mathrm{KBM}(7,7 \%)$ dan merangkum pembelajaran (6,7\%). Adapun aktifitas siswa yang mengalami peningkatan adalah membaca buku $(12,1 \%)$, menyajikan hasil pembelajaran $(4,6 \%)$, menanggapi/mengajukan pertanyaan/ide $(5,4 \%)$, dan mengerjakan tes evaluasi $(10,8 \%)$.

Terlihat bahwa nilai rata-rata prestasi belajar siswa adalah 7,29 dan ketuntasan belajar mencapai $81,58 \%$ atau ada 31 siswa dari 38 siswa sudah tuntas belajar. Hasil ini menunjukkan bahwa pada siklus II ini ketuntasan belajar secaraa klasikal telah mengalami peningkatan sedikit lebih baik dari siklus I. Adanya peningkatan hasil belajar siswa ini karena setelah guru menginformasikan bahaw setiap akhir pelajaran akan selalu diadakan tes sehingga pada pertemuan berikutnya siswa lebih termotivasi ntk belajar.

Selain itu siswa juga sudah mulai mengerti apa yang dimaksudkan dan diinginkan guru dengan menerapkan metode pembelajarn kooperatif model STAD.

Analisis data penelitian Siklus I Ranah Psikomotor, Siswa yang mendapat nilai 60 tidak ada. Siswa yang mendapat niali tujuh puluh sebanyak $15(38,46 \%)$, Siswa yang mendapat nilai 80 sebanyak $24(61,54 \%)$, Berarti siswa yang mendapat nilai di atas 70 sebanyak $61,54 \%$, secaraa klasikal termasuk kategori belum tuntas.

Ranah Afektif, Siswa yang mendapat nilai C sebanyak 6 (15,38\%), Siswa yang mendapat nilai B sebanyak $26(66,67 \%)$, Siswa yang mendapat nilai A sebanyak 7 (17,95\%), Berarti siswa yang mendapat nilai di atas $\mathrm{C}$ sebanyak $84,62 \%$, secaraa klasikal termasuk kategori tuntas.

Refleksi, Dalam pelaksanaan kegiatan belajar diperoleh informasi dari hasil pengamatan sebagai berikut : Memotivasi siswa. Membimbing siswa merumuskan kesimpulan/menemukan konsep. Pengelolaan waktu

Pelaksanan kegiatan belajar pada Siklus II ini masih terdapat kekurangan-kekurangan. Maka perlu adanya revisi untuk dilaksanakan pada siklus II antara lain : (1) Guru dalam memotivasi siswa hendaknya dapat membuat siswa lebih termotivasi selama proses belajar mengajar berlangsung. (2) Guru harus lebih dekat dengan siswa sehingga tidak ada perasaan takut dalam diri siswa baik untuk 


\section{Jurnal Ilmiah Pendidikan Scholastic}

mengemukakan pendapat atau bertanya. (3) Guru harus lebih sabar dalam membimbing siswa merumuskan kesimpulan/menemukan konsep. (4) Guru harus mendistribusikan waktu secaraa baik sehingga kegiatan pembelajaran dapat berjalan sesuai dengan yang diharapkan. (5) Guru sebaiknya menambah lebih banyak contoh soal dan meberi soal-soal-soal latihan pada siswa untuk dikerjakan pada setiap kegiatan belajar mengajar.

Siklus III, Tahap Perencanaan, Pada tahap ini peneliti mempersiapkan perangkat pembelajaran yang terdiri dari rencana pelajaran 3 , soal tes formatif 3 dan alat-alat pengajaran yang mendukung. Selain itu juga dipersiapkan lembar observasi pengelolaan metode pembelajaran kooperatif model STAD dan lembar observasi aktifitas guru dan siswa.

Tahap Kegiatan dan Pengamatan, Pelaksanaan kegiatan belajar mengajar untuk siklus III dilaksanakan pada tanggal 18 Oktober 2016 di kelas $X$ dengan jumlah siswa 38 siswa. Pelaksanaan metode pembelajaran kooperatif model STAD melalui tahapan sebagai berikut: (1) Pelaksanaan pembelajaran, (2) Diskusi kelompok, (3) Tes, (4) Penghargaan kelompok, (5) Menentukan nilai individual dan kelompok. Dalam hal ini peneliti bertindak sebagai pengajar, sedangkan yang bertindak sebagai pengamat adalah seorang guru PKn dan Wali Kelas X Adapun proses belajar mengajar mengacu pada rencana pelajaran dengan memperhatikan revisi pada siklus II, sehingga kesalahan atau kekurangan pada siklus II tidak terulang lagi pada siklus III. Pengamatan (observasi) dilaksanakan bersamaan dengan pelaksanaan belajar mengajar.

Pada akhir proses belajar mengajar siswa diberi tes formatif III dengan tujuan untuk mengetahui tingkat keberhasilan siswa dalam proses belajar mengajar yang telah dilakukan. Instrument yang digunakan adalah tes formatif III dengan tujuan untuk mengetahui tingkat keberhasilan siswa dalam proses belajar mengajar yang telah dilakukan. Instrument yang digunakan adalah tes formatif III. Adapun data hasil penelitian pada siklus III adalah sebagai berikut : Keterangan : Nilai

Kriteria (1) : Tidak Baik (2) : Kurang Baik (3) : Cukup Baik (4) : Baik

Dari tabel di atas, dapat dilihat aspekaspek yang diamati pada kegiatan belajar mengajar (siklus III) yang dilaksanakan oleh guru dengan menerapkan metode pembelajaran kooperatif model STAD mendapatkan penilaian cukup baik dari pengamat adalah memotivasi siswa, membimbing siswa merumuskan kesimpulan/menemukan konsep, dan pengelolaan waktu.

Penyempurnaan aspek-aspek diatas dalam menerapkan metode pembelajaran kooperatif model STAD diharapkan dapat berhasil semaksimal mungkin.

Berdasarkan tabel diatas tampak bahwa aktivitas guru yang paling dominan pada siklus III adalah membimbing dan mengamati siswa dalam menemukan konsep yaitu 22,6\%, sedangkan aktivitas menjelaskan materi yang sulit dan memberi umpan balik/evaluasi/tanya jawab menurun masing-masing sebesar (10\%), dan (11,7\%). Aktivitas lain yang mengalami peningkatan adalah mengkaitkan dengan pelajaran sebelumnya (10\%), menyampiakan materi/strategi /langkah-langkah (13,3\%), meminta siswa menyajikan dan mendiskusikan hasil kegiatan (10\%), dan membimbing siswa merangkum pelajaran (10\%).

Adapun aktivitas ynag tidak menglami perubahan adalah menyampaikan tujuan $(6,7 \%)$ dan memotivasi siswa $(6,7 \%)$.

Sedangkan untuk aktivitas siswa yang paling dominan pada siklus III adalah bekerja dengan sesama anggota kelompok yaitu $(22,1 \%)$ dan mendengarkan/memperhatikan penjelasan guru (20,8\%), aktivitas yang mengalami peningkatan adalah membaca buku siswa $(13,1 \%)$ dan diskusi antar siswa/antara siswa dengan guru $(15,0 \%)$. Sedangkan aktivitas yang lainnya mengalami penurunan.

Berdasarkan data hasil penelitian diperoleh nilai rata-rata tes formatif sebesar 7,97 dan dari 38 siswa yang telah tuntas sebanyak 36 siswa dan 2 siswa belum mencapai ketuntasan belajar. Maka secara klasikal ketuntasan belajar yang telah tercapai sebesar 94,74\% (termasuk kategori tuntas). Hasil pada siklus III ini mengalami peningkatan lebih baik dari siklus II.

Adanya peningkatan hasil belajar pada siklus III ini di pengaruhi oleh adanya peningkatan kemampuan guru dalam menerapkan metode pembelajaran kooperatif moel STAD sehingga siswa menjadi lebih terbiasa dengan pembelajaran seperti ini sehingga siswa lebih mudah dalam memahami materi yang telah diberikan.

Refleksi , Pada tahap ini akan dikaji apa yang telah terlaksana dengan baik maupun yang masih kurang baik dalam proses belajar mengajar dengan penerapan metode pembelajaran kooperatif model STAD. Dari data-data yang 


\section{Jurnal Ilmiah Pendidikan Scholastic}

telah diperoleh dapat diuraikan sebagi berikut : 1) Selama proses belajar mengajar guru telah mekasanakan semua pembeljaran dengan baik. Meskipun ada beberapa aspk yang belum sempurna, tetapi presentase pelaksanaanya untuk masing-masing aspek cukup besar. 2) Berdasarkan data hasil pengamatan diketahui bahwa siswa aktif selama proses belajar mengajar berlangsung. 3) Kekurangan pada siklus-siklus sebeelumnya sudah mengalami perbaikan dan peningkatan sehingga menjadi lebih baik. 4) Hasil belajar siswa paa siklus III mencapai ketuntasan.

Revisi Pelaksanaan, Pada siklus III guru

\section{KESIMPULAN DAN SARAN}

Berdasarkan hasil penelitian yang telah dipaparkan selama tiga siklus, hasil seluruh pembahasan serta analisis yang tela dilakukan dapat disimpulkan sebagai berikut : 1) Metode pembelajaran kooperatif model STAD dapat meningkatkan kualitas pembelajaran PKn. 2) Metode pembelajaran kooperatif model STAD memiliki dampak positif dalam meningkatkan prestsi belajar siswa yang ditandai dengan peningkatan ketuntasan belajar siswa dalam setiap siklus, yaitu siklus I $(68,42 \%)$, siklus II $(81,58 \%)$, siklus III $(94,74 \%)$. 3) Metode pembelajaran kooperatif model STAD dapat menjadikan siswa merasa dirinya mendapat perhatian dan kesempatan untuk menyampaikan pendapat, gagasan, ide, dan pertanyaan.

Siswa dapat bekerja secara mandiri maupun kelompok, serta mampu mempertanggungjawabkan tugas individu maupun kelompok. (2) Penerapan metode pembelajaran kooperatif model STAD mempunyai pengaruh positif, yaitu dapat meningkatkan motivasi belajar siswa.

Saran

Dari hasil penelitian yang diperoleh dari uraian sebelum agar proses belajar mengajar PKn telah menerapkan metode pemebelajaran kooperatif model STAD dengan baik dan dilihat dari kativitas siswa serta hasil belajar siswa pelaksanaan proses belajar mengajar sudah berjalan dengan baik. Maka tidak diperlukan rvisis terlau banyak, tetapi yang perlu diperhatikan untuk tindakan selanjutnya adalah memaksimalkan dan mempertahankan apa yang telah ada dengan tujuan agar pelaksanaan proses belajar mengajar selanjutnya penerapan metode pembelajaran kooperatif model STAD dapat meningkatkan proses belajar mengajar, sehingga tujuan pembelajaran dapat tercapai.

lebih efektif dan lebih memberikan hasil yang optimal bagi siswa, maka disampaikan saran sebagai berikut : 1) Untuk melaksanakan metode pembelajaran kooperatif model STAD memerlukan persiapan yang cukup matang, sehingga guru harus mampu menentukan atau memilih topik yang benar-benar bisa diterapkan dengan Metode pembelajaran kooperatif model STAD dalam pross belajar mengajar sehingga memperoleh hasil yang optimal. 2) Dalam rangka meningkatkan prestasi belajar siswa, guru hendaknya lebih sering melatih siswa dengan berbagai metode pengajaran, walau dalam taraf yang sederhana, dimana siswa nantiny dapat menemukan pengetahuan baru, memperoleh konsep dan keterampilan, sehingga siswa berhasil atau mampu memecahkan masalahmasalah yang dihadapi. 3) Perlu adanya penelitian yang lebih lanjut, karena hasil penelitian ini hanya dilakukan di kelas X, SMA Negeri 2 Sutera Tahun Pelajaran 2016/2017. 4) Untuk peneltian yang serupa hendaknya dilakukan perbaikan-perbaikan agar diperoleh hasil yang lebih baik.

\section{DAFTAR PUSTAKA}

Ali, Muhammad. 1996. Guru Dalam Proses Belajar Mengajar. Bandung: Sinar Baru Algesindon .

Arikunto, Suharsimi. 1993. Manajemen Mengajar Secaraa Manusiawi. Jakarata: Rineksa Cipta

Arikunto, Suharsimi. 2001.Dasar-dasar Evaluasi
Pendidikan. Jakarta: Bumi Aksara

Arikunto, Suharsimi. 2002. Prosedur Penelitian Suatu Pendekatan Praktek. Jakarta: Rineksa Cipta.

Azhar, Lalu Muhammad. 1993. Proses Belajar Mengajar Pendidikan. Jakarta: Usaha Nasional. 
Daroeso, Bambang. 1989. Dasar dan Konsep Pendidikan Moral Pancasila. Semarang: Aneka Ilmu.

Djamarah,Syaiful Bahri. 2002. Strategi Belajar Mengajar. Jakarta: Rineksa Putra.

Djamarah,Syaiful Bahri. 2002. psikologi belajar. Rineksa Putra.
Felder, Richad M. 1994. Cooperative Learning In The Technical Corse, (online), (PcllldlMy\% DocumentlCoop \% 20 Report.

Hadi, Sutrisno. 1982. metodologi research, jilid I.yogayakarta: yp. Fak. Psikologi UGM. 